\title{
Intoxicação por monensina em bovinos associada a suplementação mineral proteica de umidade baixa
}

Nathasha F Marcelino, Victor Thiago P Pinheiro, Paulo José B Queiroz, Paulo Henrique J da Cunha, Cairo HS de Oliveira`

Escola de Veterinária e Zootecnia, Setor de Medicina Veterinária Preventiva, Universidade Federal de Goiás (UFG), Goiânia, GO, Brasil

*Autor correspondente

e-mail: cairo@ufg.br

\section{Resumo}

Antibióticos ionóforos possuem propriedades coccidiostáticas, antimicrobianas e reguladoras do $\mathrm{pH}$ ruminal, sendo usados como melhoradores de desempenho e para fins terapêuticos. As intoxicações ocorrem por erros na dosagem, falhas na mistura, fornecimento a espécies mais sensíveis ou associação com drogas que potencializam seu efeito. 0 objetivo do trabalho é relatar a intoxicação por monensina, pelo uso de suplementação com mistura mineral proteica de umidade baixa (MUB) em bovinos de corte. No mês de novembro de 2016, realizou-se uma visita técnico-veterinária a uma propriedade de bovinocultura de corte localizada no município de Nova Crixás, Goiás. Cerca de 160 bovinos, nelores, machos, foram colocados em um piquete de Andropogon e receberam suplementação com MUB 46 MVP + Monensina (Ridley, EUA) (piquete A); outros 29 bovinos, mestiços, machos, foram alocados em outro piquete com características semelhantes (piquete B). Decorridos 30 dias, quatro animais morreram no piquete $\mathrm{A}$ e um no B, tendo os funcionários suspeitado de intoxicação por plantas tóxicas. Durante a visita não foi observado animal com sinal clínico evidente, contudo foi relatado que durante a movimentação para o manejo, os animais apresentavam fraqueza muscular, relutância ao movimento, andar cambaleante, tremores musculares, queda e morte em poucos minutos. Na inspeção dos piquetes não foi observada a presença de plantas tóxicas conhecidas. Entretanto, relatava-se a ingestão de uma planta de caráter toxico desconhecido, que apresentava boa palatabilidade, sendo observada a ingestão espontânea pelos bovinos. Foi realizada a coleta de folhas verdes para fornecimento a dois coelhos, os quais ingeriram 44 gramas/dia, durante 10 dias. Os coelhos não manifestaram alteração clínica, hematológica e de bioquímica sérica. Os bovinos eram suplementados com 10 MUB (50 kg/cada) para cada 25-30 animais, gerando consumo médio de 671,87 gramas/animal/ dia. 0 fabricante recomendava a oferta de 1 MUB para 25-30 animais, esperando um consumo médio de 140 
a 160 gramas/animal. Devido à dificuldade para transportar os recipientes de MUB até o pasto, o produtor aumentou a oferta para diminuir a frequência do transporte. A pastagem apresentava-se em condição ruim, favorecendo o consumo. Coletou-se sangue total e soro de sete bovinos para exames hematológicos e bioquímicos. Os resultados indicaram a presença de intensa lesão muscular pelo aumento dos valores séricos das enzimas DLH e CK. Devido aos achados epidemiológicos, histórico, exames laboratoriais e ausência de planta tóxica na pastagem que justificasse o quadro observado, o diagnóstico foi de intoxicação por monensina. A DL0 da monensina para bovinos é de $10 \mathrm{mg} / \mathrm{kg}$ e os animais ingeriam em média 671,87 mg por dia. Considerando o peso médio dos animais, a dose de monensina ingerida foi de $2,4 \mathrm{mg} / \mathrm{Kg} / \mathrm{dia}$. Conclui-se que a intoxicação ocorreu em animais que ingeriram valores superiores à média do grupo, e que apresentaram maior sensibilidade, resultando em 2,64\% de mortalidade. 